\title{
Bacterial Pneumonia in Captive Wild Boars in Southern Brazil - Etiological and Pathological Causes
}

\author{
Natalha Biondo ${ }^{1}$, Karine Ludwig Takeuti ${ }_{\odot}$, Julia Helena Montes ${ }^{1}$, \\ Laura Lopes de Almeida ${ }^{2}$, Caroline Pinto de Andrade ${ }^{3}$, Priscila Zlotowski ${ }^{3}$, \\ David Driemeier ${ }_{\infty}^{3} \&$ David Emilio Santos Neves de Barcellos ${ }_{\odot}^{1}$
}

\begin{abstract}
Background: Respiratory diseases are one of the major health issues described in intensive pig production, causing important economic losses. However, there is little information on the prevalence, etiology and clinical-pathological presentation of these diseases in wild boars. For this reason, this work investigated the presence in captive wild boars of pneumonic lesions and bacterial pathogens commonly detected and associated with respiratory diseases in domestic pigs.

Materials, Methods \& Results: A total of 226 captive wild boar lungs from two farms were examined in a slaughterhouse in Southern Brazil. The pneumonic lesions were classified as cranioventral, dorsocaudal, and disseminated, and the quantification of lesions was calculated. From the total of 226 lungs, 121 were collected for laboratory examination. Lungs with macroscopic lesions suggestive of pneumonia were collected for histological, bacteriological and molecular analysis. The molecular analysis was performed to detect the presence of Actinobacillus (A.) pleuropneumoniae, Glaesserella $(G$.) parasuis, Mycoplasma (M.) hyopneumoniae, Mycoplasma (M.) hyorhinis and Streptococcus (S.) suis serotype 2. The percentages of histological lesions and bacterial agents and their association were calculated. Cranioventral consolidation (75.2\%) was the most prevalent macroscopic lung lesion, followed by disseminated (21.5\%) and dorsocaudal (3.3\%) distribution. Microscopically, chronic lesions were the most prevalent, representing $70.2 \%$ of the lungs. Moreover, BALT hyperplasia was present in $86.5 \%$ of the lungs, suppurative bronchopneumonia in $65.7 \%$, and alveoli infiltrate in $46.8 \%$. Six bacterial pathogens commonly described as agents of pig pneumonia were identified by bacterial or molecular methods: Pasteurella (P.) multocida, S. suis, M. hyopneumoniae, A. pleuropneumoniae, G. parasuis and M. hyorhinis. Twenty-eight different combinations of pathogens were identified in 84 samples $(69.4 \%)$. The most common combinations were: $M$. hyopneumoniae and A. pleuropneumoniae (13.1\%), M. hyopneumoniae, G. parasuis and M. hyorhinis (10.7\%), and M. hyopneumoniae, A. pleuropneumoniae and G. parasuis (8.3\%). Additionally, M. hyopneumoniae was the most frequent pathogen detected in this study, representing $58.7 \%$ of the samples. The detection of $M$. hyopneumoniae and M. hyorhinis by PCR was associated with the presence of BALT hyperplasia $(P<0.05)$ and there was also an association between the detection of $M$. hyopneumoniae by PCR and suppurative bronchopneumonia $(P<0.05)$. In addition, a significant association $(P<0.05)$ between the detection of $M$. hyopneumoniae and A. pleuropneumoniae by PCR and the histological classification (acute, subacute or chronic lesions) was observed.

Discussion: The results of this study were similar to those observed in slaughtered domestic pigs, although, the detection of opportunist pathogens was less frequent than that usually described in pig pneumonia. The high prevalence of pneumonia in captive wild boars at slaughter and the similar characteristics of pneumonia in captive wild boars and domestic pigs suggest that the close phylogenetic relationship between pigs and wild boars could influence the susceptibility of both species to the colonization of the same pathogens, indicating that captive wild boars raised in confined conditions could be predisposed to respiratory diseases, similar to domestic pigs.
\end{abstract}

Keywords: Mycoplasma hyopneumoniae, lung consolidation, slaughter, Sus scrofa, swine.

DOI: $10.22456 / 1679-9216.118917$ 


\section{INTRODUCTION}

Respiratory diseases represent one of the major health problems in pig production due to mortality, decreased daily weight gain and costs with vaccination or antibiotic treatment [6,27]. Pneumonia in domestic pigs is frequently associated with Mycoplasma (M.) hyopneumoniae, which is the most important respiratory pathogen in Brazilian pig herds [25,30]. However, Actinobacillus (A.) pleuropneumoniae and Influenza A virus (IAV) also act as primary pathogens $[14,35,49]$ and opportunistic agents such as Glaesserella $(G$.) parasuis (formerly Haemophilus parasuis) and Pasteurella (P.) multocida may aggravate these infections $[8,14,49]$.

There are few studies on the etiology of pneumonia in wild boars $[4,17,41,48]$, especially in Brazil $[20,40,43]$. Moreover, we did not find references of respiratory diseases in captive wild boars raised in Brazil, except for a clinical report which demonstrated the occurrence of lung lesions characterized by cranioventral consolidation and pulmonary gross lesions typical of lobular bronchopneumonia associated with M. hyopneumoniae in wild boars [11]. Additionally, Biondo et al. [5], performed the first report of a reassortant human-like H1N2 Influenza virus infection in captive wild boars in Brazil.

There is a lack of information regarding pneumonia in captive wild boars, impacting on the knowledge of their role in the epidemiology and transmission of infectious pathogens to pigs. In the present work we aimed to assess lungs of captive wild boars at slaughter in order to investigate the pneumonic lesions and the presence of bacterial pathogens commonly detected and related to respiratory disease in pigs.

\section{MATERIALS AND METHODS}

\section{Experimental design}

A total of 226 lungs of captive wild boars ( $S u s$ scrofa) were assessed during 4 visits to a slaughterhouse with federal inspection in the state of Rio Grande do Sul, Brazil, which is endemic for several pathogens responsible for pneumonia in pigs, and PRRSv (Porcine Reproductive and Respiratory Syndrome virus) negative. The animals were 7 months old, and they were raised in 2 different farms.

\section{Lungs examination and sampling}

The criteria used to select lungs was the presence of any proportion of pneumonic lesion.
The gross lesions were observed regarding the presence of lung consolidation, nodules, abscesses and pleuritis. Each lung was scored regarding the distribution of lung consolidation, which was classified as: cranioventral (consolidation in cranial, medium, intermediary, and anterior portion of caudal lobes), dorsocaudal (lesion in the dorsal region of caudal lobes) and disseminated (lesions distributed in all lobes). Quantification of lesions was performed in each lobe individually [33]. The scores from all lobes were recorded in order to obtain a final score from each animal. Fragments of lung samples from areas with lesions of consolidation measuring $6 \times 6$ $\mathrm{cm}$ were stored in individual plastic bags and kept refrigerated $\left(4-8^{\circ} \mathrm{C}\right)$ for bacteriological analysis and a second sample measuring $2 \times 2 \mathrm{~cm}$ was fixed in buffered formalin solution at $10 \%$ for histopathological examination. Additionally, bronchial swabs were collected from each lung and stored at $-20^{\circ} \mathrm{C}$ for molecular analysis.

\section{Bacteriological assay}

Briefly, samples were cultivated on blood Agar ${ }^{1}$ added with $5 \%$ ovine blood and incubated in aerobic $\left(37^{\circ} \mathrm{C}\right.$ for 24 to $\left.48 \mathrm{~h}\right)$ and microaerophilic conditions (oxygen tension of 10\%) with a source of $\mathrm{V}$ factor (Staphylococcus aureus streak) and incubated at $37^{\circ} \mathrm{C}$ for 48-72 h. An additional culture was performed in Mac Conkey agar ${ }^{1}$ and incubated in aerobiosis $\left(37^{\circ} \mathrm{C}\right.$ for 24 to $48 \mathrm{~h}$ ) [21].

\section{Histopathological assay}

Samples were processed according to conventional methods for histological analysis [34]. Masson's trichrome staining was carried out following the manufacturer's protocol (EasyPath Ref. EP11-20013) to differentiate collagen and fibrin polyps. Ziehl-Neelsen carbolfuchsin staining was performed for the detection of acid alcohol resistant bacilli [34] when giant cells were observed. The histological lesions were classified in Acute: neutrophilic inflammatory infiltrate without another component of chronic infection; Subacute: samples with neutrophils and mild to moderate BALT (bronchus associated lymphoid tissue) hyperplasia; Chronic: moderate to severe BALT hyperplasia, bronchial and bronchiolar epithelium hyperplasia, presence of polyps, giant cells and infiltrate of lymphocytes and macrophages [14]. 


\section{Molecular assay}

DNA was extracted from bronchial swabs using a commercial kit QiAmp DNA minikit ${ }^{2}$, according to manufacturer's instructions. Mycoplasma hyopneumoniae [47], M. hyorhinis [45], A. pleuropneumoniae [10] and G. parasuis [28] were assessed by PCR. Samples with isolation of Streptococcus sp. were differentiated by PCR in serotype 2 and subunit $16 \mathrm{~S}$ (any serotype except serotype 2) [22].

\section{Statistical analysis}

The analysis was performed with "Statistical Analysis System" [39]. The percentage of lesions, bacterial pathogens and association analysis were performed with FREQ procedure. The qui-squared or Fisher exact test were used to verify associations with $5 \%$ probability.

\section{RESULTS}

From the total of 226 lungs, 56.2\% (127/226) showed macroscopic lesions of consolidation, and 121 were collected for laboratory examination. The other lungs were not sampled due to chronic lesions of parietal pleuritis, which was not the focus of this work. The average of lung lesioned area was $13.6 \%$ and the most prevalent macroscopic lung lesion was the cranioventral consolidation (75.2\%), followed by disseminated lesions $(21.5 \%)$ and dorsocaudal location, representing $3.3 \%$ of the lungs (Table 1 ). In addition, other lung lesions included healing lesions (13.7\%), mild focal pleurisies $(3.3 \%)$ and necro-hemorrhagic nodule with pleurisies $(0.8 \%)$.

Histopathological evaluation revealed that chronic lesions were most frequent $(70.2 \%)$, fol- lowed by subacute (12.4\%) and acute lesions (9.1\%). Moreover, lungs with no histopathological lesions represented $8.3 \%$ of the samples, which showed cranioventral distribution (Table 1). The microscopic lesions are described in Table 2 and the most prevalent findings were BALT hyperplasia (86.5\%), suppurative bronchopneumonia (65.7\%), and the presence of alveoli infiltrate $(46.8 \%)$.

Six bacterial pathogens commonly described as pig pneumonic agents were identified by bacterial or molecular evaluation: P. multocida, S. suis, M. hyopneumoniae, A. pleuropneumoniae, G. parasuis and $M$. hyorhinis. Twenty-eight different combinations of pathogens were identified in 84 samples (69.4\%). Mycoplasma hyopneumoniae was the most frequent pathogen detected in this study, representing $58.7 \%$ of the samples. The most common combinations were: $M$. hyopneumoniae and A. pleuropneumoniae (13.1\%), M. hyopneumoniae, G. parasuis and M. hyorhinis (10.7\%), and $M$. hyopneumoniae, A. pleuropneumoniae and $G$. parasuis $(8.3 \%)$.

The frequency of identification of each pathogen by bacteriological and molecular examination and their association with histological findings are presented on Table 3. The detection of M. hyopneumoniae and M. hyorhinis by PCR were associated with the presence of BALT hyperplasia and there was also an association between detection of M. hyopneumoniae by PCR and suppurative bronchopneumonia $(P<0.05)$. In addition, a significant association $(P$ $<0.05)$ between the detection of $M$. hyopneumoniae and A. pleuropneumoniae by PCR and the histological classification (acute, subacute or chronic lesions) was observed (Table 4).

Table 1. Location of 121 macroscopic lung lesions of captive slaughtered wild boars according to the histopathological classification.

\begin{tabular}{cccccc}
\hline \multicolumn{5}{c}{ Histopathological classification } \\
\hline Macroscopic distribution & Acute $(\mathrm{n}=11)$ & Subacute $(\mathrm{n}=15)$ & Chronic $(\mathrm{n}=85)$ & No change $(\mathrm{n}=10)$ Total $(\mathrm{n}=121)$ \\
\hline Cranioventral & $5.5 \%(5)$ & $11.0 \%(10)$ & $72.5 \%(66)$ & $11.0 \%(10)$ & $75.2 \%(91)$ \\
Dorsocaudal & $75.0 \%(3)$ & $0.0 \%(0)$ & $25.0 \%(1)$ & $0.0 \%(0)$ & $3.3 \%(4)$ \\
Disseminated & $22.6 \%(3)$ & $19.2 \%(5)$ & $69.2 \%(18)$ & $0.0 \%(0)$ & $21.5 \%(26)$ \\
\hline Total & $9.1 \%(11)$ & $12.4 \%(15)$ & $70.2 \%(85)$ & $8.3 \%(10)$ & $100.0 \%(121)$ \\
\hline
\end{tabular}

${ }^{1}$ Lungs without microscopic lesions. 
N. Biondo, K.L. Takeuti, J.H. Montes, et al. 2021. Bacterial Pneumonia in Captive Wild Boars in Southern Brazil - Etiological and Pathological Causes.

Table 2. Histopathological lesions presented in 111 lungs of captive slaughtered wild boars with pneumonia.

\begin{tabular}{|c|c|c|c|c|}
\hline \multirow{2}{*}{ Histopathological lesion } & \multicolumn{4}{|c|}{ Histopathological classification } \\
\hline & Acute $(n=11)$ & Subacute $(\mathrm{n}=15)$ & Chronic $(\mathrm{n}=85)$ & Total $(n=111)$ \\
\hline \multicolumn{5}{|l|}{ BALT hyperplasia $^{1}$} \\
\hline 0 & $54.5 \%(6)$ & $6.7 \%(1)$ & $9.4 \%(8)$ & $13.5 \%(15)$ \\
\hline+ & $36.3 \%(4)$ & $26.6 \%(4)$ & $15.3 \%(13)$ & $18.9 \%(21)$ \\
\hline++ & $9.1 \%(1)$ & $66.6 \%(10)$ & $45.9 \%(39)$ & $45.1 \%(50)$ \\
\hline+++ & $0.0 \%(0)$ & $0.0 \%(0)$ & $29.4 \%(25)$ & $22.5 \%(25)$ \\
\hline \multicolumn{5}{|c|}{ Suppurative bronchopneumonia $^{2}$} \\
\hline 0 & $27.2 \%(3)$ & $20.0 \%(3)$ & $37.6 \%(32)$ & $34.3 \%(38)$ \\
\hline+ & $18.1 \%(2)$ & $33.3 \%(5)$ & $31.7 \%(27)$ & $30.6 \%(34)$ \\
\hline++ & $27.2 \%(3)$ & $33.3 \%(5)$ & $22.3 \%(19)$ & $24.3 \%(27)$ \\
\hline+++ & $27.2 \%(3)$ & $13.3 \%(2)$ & $8.2 \%(7)$ & $10.8 \%(12)$ \\
\hline Bronchitis & $0.0 \%(0)$ & $0.0 \%(0)$ & $11.7 \%(10)$ & $9.0 \%(10)$ \\
\hline Bronchiolitis & $27.2 \%(3)$ & $13.3 \%(2)$ & $31.7 \%(27)$ & $28.8 \%(32)$ \\
\hline \multicolumn{5}{|l|}{ Polyps $^{3}$} \\
\hline Fibrin & $0.0 \%(0)$ & $0.0 \%(0)$ & $4.7 \%(4)$ & $3.6 \%(4)$ \\
\hline Collagen & $0.0 \%(0)$ & $0.0 \%(0)$ & $24.7 \%(21)$ & $18.9 \%(21)$ \\
\hline Ephitelium hiperplasy ${ }^{4}$ & $0.0 \%(0)$ & $26.6 \%(4)$ & $10.6 \%(9)$ & $11.7 \%(13)$ \\
\hline Alveoli fibrin ${ }^{5}$ & $9.1 \%(1)$ & $20.0 \%(3)$ & $7.0 \%(6)$ & $9.0 \%(10)$ \\
\hline \multicolumn{5}{|l|}{ Alveoli infiltrate } \\
\hline Neutrophil & $18.1 \%(2)$ & $0.0 \%(0)$ & $0.0 \%(0)$ & $1.8 \%(2)$ \\
\hline Macrophage & $9.1 \%(1)$ & $6.7 \%(1)$ & $20.0 \%(17)$ & $17.1 \%(19)$ \\
\hline Giant cell (GC) & $0.0 \%(0)$ & $0.0 \%(0)$ & $2.3 \%(2)$ & $1.8 \%(2)$ \\
\hline Mixed & $36.3 \%(4)$ & $53.3 \%(8)$ & $16.5 \%(14)$ & $23.4 \%(26)$ \\
\hline Macropahge + GC & $0.0 \%(0)$ & $0.0 \%(0)$ & $3.5 \%(3)$ & $2.7 \%(3)$ \\
\hline
\end{tabular}

${ }^{1}$ Hyperplasia of lymphoid tissue associated to bronchi; ${ }^{2}$ Presence of neutrophil in bronchi and bronchioles; ${ }^{3}$ Presence of polyps in bronchi and alveoli; ${ }^{4}$ Epithelium hyperplasia of bronchi and bronchiole; ${ }^{5}$ Exsudation of fibrin in alveoli; $0=$ absence; + mild; ++ moderate; +++ severe.

Table 3. Percentage of each bacterial pathogen detected by bacteriology and PCR and its association with BALT hyperplasia and suppurative bronchopneumonia by histopathological examination.

\begin{tabular}{|c|c|c|c|c|c|c|}
\hline \multirow{3}{*}{ Pathogens } & \multicolumn{3}{|c|}{ BALT hyperplasia $^{1}$} & \multirow{3}{*}{$\begin{array}{c}\text { Absence } \\
(\mathrm{n}=38) \\
\%(\mathrm{~N})\end{array}$} & \multirow{3}{*}{$\begin{array}{c}\text { Presence } \\
(\mathrm{n}=73) \\
\%(\mathrm{~N})\end{array}$} & \multirow{3}{*}{$P$-value* } \\
\hline & $\begin{array}{c}\text { Absence } \\
(n=15)\end{array}$ & $\begin{array}{c}\text { Presence } \\
(n=96)\end{array}$ & $P$-value & & & \\
\hline & & & & & & \\
\hline \multicolumn{7}{|l|}{ Bacteriology } \\
\hline P. multocida & $4.0(1)$ & $10.4(10)$ & 0.320 & $12.5(5)$ & $6.8(5)$ & 0.290 \\
\hline \multicolumn{7}{|l|}{ S. suis } \\
\hline Serotype 2 & $4.0(1)$ & $5.2(5)$ & 0.804 & $2.08(1)$ & $6.8(5)$ & 0.237 \\
\hline Others serotypes ${ }^{2}$ & $0.0(0)$ & $5.2(5)$ & 0.243 & $2.08(1)$ & $5.5(4)$ & 0.358 \\
\hline Streptococcus sp. & $4.0(1)$ & $3.1(3)$ & 0.827 & $0.0(0)$ & $5.5(4)$ & 0.099 \\
\hline \multicolumn{7}{|l|}{ PCR } \\
\hline M.hyopneumoniae & $36.0(6)$ & $64.6(62)$ & 0.009 & 43.7 (17) & $68.5(50)$ & 0.006 \\
\hline A.pleuropneumoniae & $60.0(9)$ & $45.8(44)$ & 0.206 & $56.2(22)$ & $43.8(32)$ & 0.181 \\
\hline G. parasuis & $40.0(6)$ & $52.1(50)$ & 0.281 & $45.8(18)$ & $52.0(38)$ & 0.503 \\
\hline M. hyorhinis & $24.0(4)$ & $45.8(44)$ & 0.048 & $35.4(14)$ & $45.2(33)$ & 0.284 \\
\hline
\end{tabular}

${ }^{1}$ Hyperplasia of lymphoid tissue associated to bronchi; ${ }^{2}$ Classification by PCR $+(16 \mathrm{~S} \mathrm{r} \mathrm{RNA):} \mathrm{Streptococcus} \mathrm{suis} \mathrm{any} \mathrm{serotype} \mathrm{except} 2 . * P$ value $<0.05$ indicates significant difference between the absence or presence of each lesion regarding the pathogen detected. 
Table 4. Pathogens detected by bacteriology and PCR and their association with histopathological classification of 121 lungs of captive slaughtered wild boars.

\begin{tabular}{|c|c|c|c|c|c|}
\hline Pathogens & $\begin{array}{c}\text { Acute }(\mathrm{n}=11) \\
\%(\mathrm{~N})\end{array}$ & $\begin{array}{c}\text { Subacute } \\
(\mathrm{n}=15) \\
\%(\mathrm{~N})\end{array}$ & $\begin{array}{c}\text { Chronic }(\mathrm{n}=85) \\
\%(\mathrm{~N})\end{array}$ & $\begin{array}{c}\text { No changes }^{1} \\
(\mathrm{n}=10) \\
\%(\mathrm{~N})\end{array}$ & $P$-value* \\
\hline \multicolumn{6}{|l|}{ Bacteriology } \\
\hline P. multocida & $18.1(2)$ & $20.0(3)$ & $5.9(5)$ & $10.0(1)$ & 0.228 \\
\hline \multicolumn{6}{|l|}{ S. suis } \\
\hline Serotype 2 & $9.1(1)$ & $0.0(0)$ & $5.9(5)$ & $0.0(0)$ & 0.602 \\
\hline Others serotypes ${ }^{2}$ & $9.1(1)$ & $13.3(2)$ & $2.3(2)$ & $0.0(0)$ & 0.171 \\
\hline Streptococcus sp. & $0.0(0)$ & $6.6(1)$ & $3.5(3)$ & $0.0(0)$ & 0.738 \\
\hline \multicolumn{6}{|l|}{ PCR } \\
\hline M. hyopneumoniae & $63.6(7)$ & $73.3(11)$ & $60.0(51)$ & $20.0(2)$ & 0.053 \\
\hline A. pleuropneumoniae & $36.3(4)$ & $53.3(8)$ & $44.7(38)$ & $90.0(9)$ & 0.042 \\
\hline G. parasuis & $45.4(5)$ & $53.3(8)$ & $51.7(44)$ & $30.0(3)$ & 0.603 \\
\hline M. hyorhinis & $45.4(5)$ & $60.0(9)$ & $41.2(35)$ & $10.0(1)$ & 0.098 \\
\hline
\end{tabular}

${ }^{1}$ Lungs which showed no lesions; ${ }^{2}$ Classification by PCR + (16S r RNA): Streptococcus suis any serotype except $2 . * P$-value $<0.05$ indicates significant difference among histopathological classifications within a line.

\section{DISCUSSION}

Cranioventral lung consolidation (reddish to gray and firm areas) suggestive of bronchopneumonia was the predominant lesion distribution observed in our study, affecting mainly the right medium and cranial lobes, similar to data obtained in pig lungs [14,18,26], which is frequently associated with $M$. hyopneumoniae infection in pigs $[42,49]$.

Regarding histopathological analysis, 70.2\% of lungs showed chronic lesions characterized by fibroplasia, BALT hyperplasia, hyperplasia of bronchial or bronchiolar epithelium, presence of bronchiolar polyps and alveolar polyp-like structures with a fibrous core, hypertrophy of the smooth muscle layer around bronchioles and alveolar ducts, and cellular infiltrates primarily consisting of lymphocytes and plasma cells [14]. These results suggest that the infection of the animals occurred several weeks prior to slaughter, however, epidemiological studies need to be carried out to assess the dynamics of infection of each pathogen in wild boars.

The BALT hyperplasia was the most prevalent histological lesion observed, which was significantly associated with $M$. hyopneumoniae detection by PCR. These data was already expected, once BALT hyperplasia is highly suggestive of pneumonia caused by $M$. hyopneumoniae due to high levels of interleukin- $\beta$ and tumor necrosis factor induced by virulent strains of the bacterium, which have a nonspecific mitogenic effect on lymphocytes, resulting in BALT hyperplasia $[2,23,24]$. Similar results have been observed $[9,17]$, which also observed association between $M$. hyopneumoniae detection by PCR and BALT hyperplasia in pigs and wild boars, respectively.

Suppurative bronchopneumonia was present in $65.7 \%$ of cases, which can be explained by the high prevalence of bacteria detected by PCR or bacteriology. In addition, there was a significant association between suppurative bronchopneumonia and the detection of $M$. hyopneumoniae. This association has already been described in pigs slaughtered in Brazil [3], and some studies have observed an increase in $M$. hyopneumoniae seroprevalence and the occurrence of suppurative bronchopneumonia [14,15,25].

Furthermore $28.8 \%$ of the samples presented bronchiolitis, which is characteristic of the infection with influenza A virus subtypes (H1N1, H1N2 and H3N2) and by H1N1pdm2009 [19,31,44]. The isolation of Influenza A virus and its subtypes in lungs of slaughtered captive wild boars has already been described [5], which supports the hypothesis that the bronchiolitis may be related to the presence of this agent in this study. However, as the aim of the study was the detection of bacterial agents of pneumonia, the detection of the Influenza A virus was not performed.

An interesting result was the presence of giant cells in $4.1 \%$ of the samples. In pig lungs, it is usually 
associated with aspiration pneumonia, foreign bodies or infection with Mycobacterium sp. [18]. However, the histopathological examination or Ziehl-Neelsen staining did not detect the presence of Mycobacterium species in the lungs of our study. In addition, polyps were present in bronchioles and alveoli in $29.4 \%$ of the samples and collagen was the predominant type. Polyps are formed in consequence of epithelial damage and are common in chronic conditions, as those found in our study. These structures have been described [14] but their importance is still unknown.

A high proportion of lung pathogens were detected by bacteriology and PCR in the slaughtered captive wild boars of our study. Mycoplasma hyopneumoniae was the most prevalent bacterium detected in our study, representing $58.7 \%$ of the lungs, which has already been detected in wild boars with clinical respiratory symptoms by other authors $[11,20,40]$. However, it was expected that the detection of M. hyopneumoniae by PCR would be related with histopathological lesions suggestive of its infection in order to associate the bacterium with lung lesions. In our study, a total of $64.6 \%$ of lungs with BALT hyperplasia was positive for M. hyopneumoniae, which is highly suggestive of its role on the etiology of pneumonia, since this lesion is characteristic of fully developed enzootic pneumonia [7]. On the other hand, $36 \%$ of samples were $M$. hyopneumoniae positive by PCR regardless the presence of BALT hyperplasia, which could be related to the chronicity of infection, and the detection of the bacterium in early stages of infection, even before the occurrence of lung lesions [32]. In addition, BALT hyperplasia is not a pathognomonic lesion for $M$. hyopneumoniae, which was already observed in association with metastrongylid parasitism in lungs of free-range wild boars in Brazil [40], but it was not observed in our lungs microscopically.

The second commonest pathogen found in our work was G. parasuis (49.6\%), which usually causes pleurisy, polyserositis or septicemia in pigs. This bacterium is frequently associated to primary viral and bacterial pathogens or immune depression [49]. In wild boars, there are few reports of infection with this agent. The available studies were the results of serological investigations and detection in carriers and suggest a role as an opportunistic agent in wild boars [29]. Glässer's disease, caused by this agent, has never been described in wild boars, but a strain isolated from the nose of wild boars was able to reproduce characteristic lesions in one domestic pig [1], suggesting the existence of virulent strains in wild boar populations, which could produce disease under the appropriate conditions.

Actinobacillus pleuropneumoniae was detected exclusively by PCR in $48.8 \%$ of the lungs of this study. However, no characteristic macroscopic or histopathological lesions (nor association with G. parasuis) were observed, such pleurisy and necro-hemorrhagic nodules. Thus, it was not possible to confirm the participation of both pathogens in the investigated pneumonic lesions, suggesting a role as secondary invaders, carriers or representing residual DNA of dead bacteria detected by PCR. Furthermore, A. pleuropneumoniae was significantly associated with different histopathological classifications (acute, subacute and chronic), and it was detected in 90\% of lungs with no microscopic lesions. In Germany, $A$. pleuropneumoniae infection status was evaluated and gross pathologic lesions typical for pleuropneumonia were not detected, even though $35.8 \%$ of the wild boars were PCR positive [35]. Furthermore, the detection of serum antibodies against $A$. pleuropneumoniae has been described in finishing captive wild boars [13], suggesting that the role of A. pleuropneumoniae and G. parasuis in pneumonia of captive wild boars needs to be better evaluated.

M. hyorhinis was identified in $41.3 \%$ of the lungs and its detection was significant associated with BALT hyperplasia. This association was previously registered in pigs experimentally infected with M. hyorhinis [16]. However, the clinical-pathological importance of this association is not clear yet, as $M$. hyorhinis is a commensal bacterium of the swine respiratory tract and the detection by PCR in lungs do not confirm its role as a lung pathogen [36]. Moreover studies are necessary to identify the role of $M$. hyorhinis in this type of lesion, since it is frequently associated with M. hyopneumoniae infections, such as in our study.

Pasteurella multocida is a common bacterium associated to pig pneumonia $[8,25,46]$. However, it was isolated in a low proportion of lungs $(9.1 \%)$ in our study, and there are no reports of the involvement of $P$. multocida in respiratory diseases in wild boar populations and its importance is still unknown. In addition, S. suis detection was also low $(9.1 \%)$ in this study, similar to previous findings in pneumonic pig lungs, which varied from 6 to $18 \%[12,14]$. In Spain, S. suis was isolated in $39.1 \%$ of hunted wild boars and several 
serotypes have been identified indicating great diversity of this pathogen within the wild boar population. The authors also observed that the isolates were genetically unrelated to those typically associated with infections in humans or pigs in Europe [38]. Moreover, S. suis isolates exhibited lower detection of virulence genes in wild boars when compared to pig isolates, which may explain the low prevalence of lung lesions in wild boars [37]. Regarding both pathogens, we hypothesize that their role as pneumonic agents in captive wild boars would be possible as secondary pathogens.

The data of the current study showed that the combination of pathogens, which represented $69.4 \%$ of the lungs, was similar to data obtained from slaughtered pigs in southern Brazil, when combinations of 2 or more pathogens was observed in up to $60 \%$ of the cases $[9,25]$. In Denmark, 148 lungs of slaughtered pigs with cranioventral bronchopneumonia were assessed and a wide range of macroscopic lesions, which were correlated with 5 species bacteria, 5 viruses and 2 mycoplasmas in different combinations were observed [14]. The results of our study suggest the etiological complexity of pneumonia in captive wild boars, similar to the involvement of several bacteria in slaughtered pigs, characterizing the Porcine Respiratory Disease Complex (PRDC).

\section{CONCLUSIONS}

The distribution of macroscopic lesions, the type of histological lesions, the high frequency of M. hyopneumoniae detection and the combination of several bacterial pathogens observed in captive wild boars of this study were similar to those found in slaughtered domestic pigs. We hypothesize that the close phylogenetic relationship between pigs and wild boars could influence the susceptibility of both species to the colonization with the same pathogens. Moreover, the high prevalence of pneumonia observed in the current study suggests that the captive wild boars raised in confined conditions also predisposes them to respiratory diseases, similar to what happens with domestic pigs.

\section{MANUFACTURERS \\ ${ }^{1}$ HiMedia Leading BioSciences Company. Mumbai, India. ${ }^{2}$ QIAGEN GmbH. Hilden, Germany.}

Acknowledgements. This work was supported by Conselho Nacional de Desenvolvimento Científico e Tecnológico (Proc. 578376/2008-3). The authors are grateful to undergraduate and graduate students from UFRGS and Cooperativa Ouro do Sul for the support.

Declaration of interest. The authors report no conflicts of interest. The authors alone are responsible for the content and writing of paper.

\section{REFERENCES}

1 Aragon V., Cerdà-Cuéllar M., Fraile L., Mombarg M., Nofrarías M., Olvera A., Sibila M., Solanes D. \& Segalés J. 2010. Correlation between clinico-pathological outcome and typing of Haemophilus parasuis field strains. Veterinary Microbiology. 142(3-4): 387-393. DOI: 10.1016/j.vetmic.2009.10.025.

2 Asai T., Okada M., Ono M., Irisawa T., Mori Y., Yokomizo Y. \& Sato S. 1993. Increased levels of tumor necrosis factor and interleukin 1 in bronchoalveolar lavage fluids from pigs infected with Mycoplasma hyopneumoniae. Veterinary Immunology and Immunopathology. 38(3-4): 253-260. DOI: 10.1016/0165-2427(93)90085-i.

3 Baraldi T.G., Cruz N.R.N., Pereira D.A., Galdeano J.V.B., Gatto I.R.H., Silva A.F.D., Panzardi A., Linhares D.C.L., Mathias L.A. \& Oliveira L.G. 2019. Antibodies against Actinobacillus pleuropneumoniae, Mycoplasma hyopneumoniae and influenza virus and their relationships with risk factors, clinical signs and lung lesions in pig farms with one-site production systems in Brazil. Preventive Veterinary Medicine. 17: 104748. DOI: 10.1016/j.prevetmed.2019.104748.

4 Baroch J.A., Gagno C.A., Lacouture S. \& Gottschalk M. 2015. Exposure of feral swine (Sus scrofa) in the United States to selected pathogens. Canadian Journal of Veterinary Research. 79(1): 74-78.

5 Biondo N., Schaefer R., Gava D., Cantão M.E., Silveira S., Mores M.A.Z., Ciacci-Zanella J.R. \& Barcellos D.E.S.N. 2014. Genomic analysis of influenza A virus from captive wild boars in Brazil reveals a human-like H1N2 influenza virus. Veterinary Microbiology. 168(1): 34-40. DOI: 10.1016/j.vetmic.2013.10.010.

6 Calderón Díaz J.A., Fitzgerald R.M., Shalloo L., Costa M.R., Niemi J., Leonard F.C., Kyriazakis I. \& Manzanilla E.G. 2020. Financial Analysis of Herd Status and Vaccination Practices for Porcine Reproductive and Respiratory Syndrome Virus, Swine Influenza Virus, and Mycoplasma hyopneumoniae in Farrow-to-Finish Pig Farms Using a BioEconomic Simulation Model. Frontiers in Veterinary Science. 7(November): 1-14. DOI: 10.3389/fvets.2020.556674. 
7 Caswell J.L. \& Williams K.J. 2016. Respiratory system. In: Jubb K.P. (Ed). Jubb, Kennedy \& Palmer's Pathology of Domestic Animals. 6th edn. St. Louis: Elsevier, pp.526-527.

8 Ciprián A., Pijoan C., Cruz T., Camacho J., Tórtora J., Colmenares G., López-Revilla R. \& De la Garza M. 1988. Mycoplasma hyopneumoniae increases the susceptibility of pigs to experimental Pasteurella multocida pneumonia. Canadian Journal of Veterinary Research. 52(4): 434-438.

9 Conti E.R., Takeuti K.L., Schwertz C.I., Bianchi R.M., Driemeier D. \& Barcellos D.E.S.N. 2021. Agents of pneumonia in slaughtered pigs in southern Brazil. Pesquisa Veterinária Brasileira. 41:e6669 . DOI: 10.1590/1678-5150PVB-6669.

10 Costa M.M., Klein C.S., Balestrin R., Schrank A., Piffer I.A., Silva S.C. \& Schrank I.S. 2004. Evaluation of PCR based on gene apxIVA associated with $16 \mathrm{~S}$ rDNA sequencing for the identification of Actinobacillus pleuropneumoniae and related species. Current Microbiology. 48(3): 189-195. DOI: 10.1007/s00284-003-4162-x.

11 Ecco R., Lazzari A.M. \& Guedes R.M.C. 2009. Pneumonia enzoótica em javalis (Sus scrofa). Pesquisa Veterinária Brasileira. 29(6): 461-468.

12 Fablet C., Marois C., Dorenlor V., Eono F., Eveno E., Jolly J.P., Le Devendec L., Kobisch M., Madec F. \& Rose N. 2012. Bacterial pathogens associated with lung lesions in slaughter pigs from 125 herds. Research in Veterinary Science. 93(2): 627-630. DOI: 10.1016/j.rvsc.2011.11.002

13 Hälli O., Ala-Kurikka E., Wallgren P. \& Heinonen M. 2014. Actinobacillus pleuropneumoniae seroprevalence in farmed wild boars in finland. Journal of Zoo and Wildlife Medicine. 45(4): 813-818. DOI: 10.1638/2014-0046.1.

14 Hansen M.S., Pors S.E., Jensen H.E., Bille-Hansen V., Bisgaard M., Flachs E.M. \& Nielsen O.L. 2010. An investigation of the pathology and pathogens associated with porcine respiratory disease complex in Denmark. Journal of Comparative Pathology. 143(2-3): 120-131. DOI: 10.1016/j.jcpa.2010.01.012.

15 Jirawattanapong P., Stockhofe-Zurwieden N., van Leengoed L., Wisselink H., Raymakers R., Cruijsen T., van der Peet-Schwering C., Nielen M. \& van Nes A. 2010. Pleuritis in slaughter pigs: Relations between lung lesions and bacteriology in 10 herds with high pleuritis. Research in Veterinary Science. 88(1): 11-15. DOI: 10.1016/j. rvsc.2009.06.007.

16 Lin J.H., Chen S.P., Yeh K.S. \& Weng C.N. 2006. Mycoplasma hyorhinis in Taiwan: Diagnosis and isolation of swine pneumonia pathogen. Veterinary Microbiology. 115(1-3): 111-116. DOI: 10.1016/j.vetmic.2006.02.004.

17 Linhares M.B., Belloy L., Origgi F.C., Lechner I., Segner H. \& Ryser-Degiorgis M.P. 2015. Investigating the role of free-ranging wild boar (Sus scrofa) in the re-emergence of enzootic pneumonia in domestic pig herds: A pathological, prevalence and risk-factor study. PLoS ONE. 10(3): 1-26. DOI: 10.1371/journal.pone.0119060.

18 López A. 2006. Respiratory System In: McGavin M.D \& J.F. Zachary J.F. (Eds). Pathologic Basis Veterinary Diseases. 4th edn. Ames: Mosby Elsevier, pp.463-558.

19 Lyoo K.S., Kim J.K., Jung K., Kang B.K. \& Song D. 2014. Comparative pathology of pigs infected with Korean H1N1, H1N2, or H3N2 swine influenza A viruses. Virology Journal. 11(1): 1-6. DOI: 10.1186/1743-422X-11-170.

20 Maciel A.L.G., Loiko M.R., Bueno T.S., Moreira J.G., Coppola M., Dalla Costa E.R., Schmid K.B., Rodrigues R.O., Cibulski S.P., Bertagnolli A.C. \& Mayer F.Q. 2018. Tuberculosis in Southern Brazilian wild boars (Sus scrofa): First epidemiological findings. Transboundary and Emerging Diseases. 65(2): 518-526. DOI: 10.1111/tbed.12734.

21 Markey B., Leonard F., Archambault M., Cullinane A. \& Maguire D. 2013. Clinical Veterinary Microbiology. 2nd edn. Dublin: Mosby Elsevier, 920p.

22 Marois C., Bougeard S., Gottschalk M. \& Kobisch M. 2004. Multiplex PCR assay for detection of Streptococcus suis species and serotypes 2 and 1/2 in tonsils of live and dead pigs. Journal of Clinical Microbiology. 42(7): 31693175. DOI: 10.1128/JCM.42.7.3169-3175.2004.

23 Messier S. \& Ross R.F. 1991. Interactions of Mycoplasma hyopneumoniae membranes with porcine lymphocytes. American Journal of Veterinary Research. 52(9): 1497-1502.

24 Meyns T., Dewulf J., de Kruif A., Calus D., Haesebrouck F. \& Maes D. 2006. Comparison of transmission of Mycoplasma hyopneumoniae in vaccinated and non-vaccinated populations. Vaccine. 24(49-50): 7081-7086. DOI: 10.1016/j. vaccine.2006.07.004.

25 Morés M.A.Z., Oliveira Filho J.X., Rebelatto R., Klein C.S., Barcellos D.E.N., Coldebella A. \& Morés N. 2015. Aspectos patológicos e microbiológicos das doenças respiratórias em suínos de terminação no Brasil. Pesquisa Veterinária Brasileira. 35(8): 725-733. DOI: 10.1590/S0100-736X2015000800004. 
26 Morrison R.B., Pijoan C., Hilley H.D. \& Rapp V. 1985. Microorganisms associated with pneumonia in slaughter weight swine. Canadian Journal of Comparative Medicine. 49(2): 129-137.

27 Nathues H., Alarcon P., Rushton J., Jolie R., Fiebig K., Jimenez M., Geurts V. \& Nathues C. 2017. Cost of porcine reproductive and respiratory syndrome virus at individual farm level - An economic disease model. Preventive Veterinary Medicine. 142: 16-29. DOI: 10.1016/j.prevetmed.2017.04.006.

28 Oliveira S., Galina L. \& Pijoan C. 2001. Development of a PCR test to diagnose Haemophilus parasuis infections. Journal of Veterinary Diagnostic Investigation. 13(6): 495-501. DOI: 10.1177/104063870101300607.

29 Olvera A., Cerdà-Cuéllar M., Mentaberre G., Casas-Diaz E., Lavin S., Marco I. \& Aragon. 2007. First isolation of Haemophilus parasuis and other NAD-dependent Pasteurellaceae of swine from European wild boars. Veterinary Microbiology. 125(1-2): 182-186. DOI: 10.1016/j.vetmic.2007.05.003.

30 Pacce V.D., Oliveira N.R., Jorge S. \& Dellagostin O.A. 2019. Occurrence of Mycoplasma hyopneumoniae in slaughter pigs from southern Brazil. Brazilian Journal of Veterinary Research and Animal Science. 56(1): 1-5. DOI: 10.11606/ issn.1678-4456.bjvras.2019.150072.

31 Pereda A., Cappuccio J., Quiroga M.A., Baumeister E., Insarralde L., Ibar M., Sanguinetti R., Cannilla M.L., Franzese D., Escobar Cabrera O.E., Craig M.I., Rimondi A., Machuca M., Debenedetti R.T., Zenobi C., Barral L., Balzano R., Capalbo S., Risso A. \& Perfumo C.J. 2010. Pandemic (H1N1) 2009 outbreak on pig farm, Argentina. Emerging Infectious Diseases. 16(2): 304-307. DOI: 10.3201/eid1602.091230.

32 Pieters M. \& Maes D. 2019. Mycoplasmosis. In: Zimmerman J.J., Karriker L.A., Ramirez A., Schawartz K.J., Stevenson G.W. \& Zhang J. (Eds). Diseases of Swine. 11th edn. Hoboken: Wiley-Blackwell, pp.863-883.

33 Piffer I. \& Brito J. 1991. Avaliação e quantificação de lesões em pulmões de suínos. In: Concórdia: Empresa Brasileira de Pesquisa Agropecuária - EMBRAPA, 12p.

34 Prophet E.B., Mills B., Arrington J.B. \& Sobin L.H. 1992. Laboratory Methods in Histotechnology. Washington: American Registry of Pathology, 279p.

35 Reiner G., Fresen C., Bronnert S., Haack I. \& Willems H. 2010. Prevalence of Actinobacillus pleuropneumoniae Infection in Hunted Wild Boars (Sus scrofa) in Germany. Journal of Wildlife Diseases. 46(2): 551-555. DOI: 10.7589/0090-3558-46.2.551.

36 Rovira A., Clavijo M.J. \& Oliveira S. 2010. Infecção por Mycoplasma hyorhinis em suínos. Acta Scientiae Veterinariae. 38(1): 9-15.

37 Sánchez del Rey V., Fernández-Garayzábal J.F., Domínguez L., Gottschalk M. \& Vela A.I. 2016. Screening of virulence-associated genes as a molecular typing method for characterization of Streptococcus suis isolates recovered from wild boars and pigs. Veterinary Journal. 209: 108-112. DOI: 10.1016/j.tvj1.2015.11.007.

38 Sánchez del Rey V., Fernández-Garayzábal J.F., Mentaberre G., Briones V., Lavín S., Domínguez L., Gottschalk M. \& Vela A.I. 2014. Characterisation of Streptococcus suis isolates from wild boars (Sus scrofa). Veterinary Journal. 200(3): 464-467. DOI: 10.1016/j.tvj1.2014.03.013.

39 SAS. SAS/STAT User's Guide. 2005.

40 Severo D.R.T., Werlang R.A., Mori A.P., Baldi K.R.A., Mendes R.E., Surian S.R.S., Coldebella A., Kramer B., Trevisol I.M., Gomes T.M.A. \& Silva V.S. 2021. Health profile of free-range wild boar (Sus scrofa) subpopulations hunted in Santa Catarina State, Brazil. Transboundary and Emerging Diseases. 68(2): 857-869. DOI: 10.1111/tbed.13752.

41 Sibila M., Mentaberre G., Boadella M., Huerta E., Casas-Díaz E., Vicente J., Gortázar C., Marco I., Lavín S. \& J. Segalés. 2010. Serological, pathological and polymerase chain reaction studies on Mycoplasma hyopneumoniae infection in the wild boar. Veterinary Microbiology. 144(1-2): 214-218. DOI: 10.1016/j.vetmic.2009.12.019.

42 Sibila M., Nofrarías M., López-Soria S., Segalés J., Valero O., Espinal A.\& Calsamiglia M. 2007. Chronological study of Mycoplasma hyopneumoniae infection, seroconversion and associated lung lesions in vaccinated and nonvaccinated pigs. Veterinary Microbiology. 122(1-2): 97-107. DOI: 10.1016/j.vetmic.2007.01.010.

43 Souza T.C.G.D., Silva V.S., Mores M.A.Z., Kramer B., Leme R.A., Silva Porto G. \& Alfieri A.A. 2021. Mycoplasma hyopneumoniae in free-living wild boars in Paraná, Brazil. Brazilian Journal of Microbiology. DOI: 10.1007/s42770021-00516-0.

44 Sreta D., Kedkovid R., Tuamsang S., Kitikoon P. \& Thanawongnuwech R. 2009. Pathogenesis of swine influenza virus (Thai isolates) in weanling pigs: An experimental trial. Virology Journal. 6: 1-11. DOI: 10.1186/1743-422X-6-34. 
N. Biondo, K.L. Takeuti, J.H. Montes, et al. 2021. Bacterial Pneumonia in Captive Wild Boars in Southern Brazil - Etiological and Pathological Causes. Acta Scientiae Veterinariae. 49: 1838.

45 Stakenborg T., Vicca J., Butaye P., Imberechts H., Peeters J., De Kruif A., Haesebrouck F. \& Maes D. 2006. A multiplex PCR to identify porcine mycoplasmas present in broth cultures. Veterinary Research Communications. 30(3): 239-247. DOI: 10.1007/s11259-006-3226-3.

46 Takeuti K.L., Watanabe T.T.N., Castro L.A., Driemeier D. \& Barcellos D.E.S.N. 2013. Caracterização histopatológica e imuno-histoquímica da pneumonia causada pela co-infecção por Pasteurella multocida e Mycoplasma hyopneumoniae em suínos. Acta Scientiae Veterinariae. 41: 1117. 6p.

47 Takeuti K.L., Barcellos D.E.S.N., Andrade C.P., Almeida L.L. \& Pieters M. 2017. Infection dynamics and genetic variability of Mycoplasma hyopneumoniae in self-replacement gilts. Veterinary Microbiology. 208: 18-24. DOI: 10.1016/j.vetmic.2017.07.007.

48 Vicente J., León-Vizcaíno L., Gortázar C., Cubero M.J., González M. \& Martín-Atance P. 2002. Antibodies to selected viral and bacterial pathogens in European wild boars from southcentral Spain. Journal of Wildlife Diseases. 38(3): 649-652. DOI: 10.7589/0090-3558-38.3.649.

49 Zimmerman J.J., Karriker L.A., Ramirez A., Schawartz K.J., Stevenson G.W. \& Zhang J. 2019. Diseases of Swine. 11th edn. Hoboken: Wiley-Blackwell, 1136p. 